(c) Group of authors, 2021

UDC 617.753

DOI - https://doi.org/10.14300/mnnc.2021.16037

ISSN - 2073-8137

\title{
THE USE OF ANTIOXIDANT THERAPY IN TREATING PEDIATRIC ACCOMMODATIVE DISORDERS IN REFRACTIVE PATHOLOGY
}

\author{
Cherednichenko N. L., Korenyak G. V., Neshta E. S., Torosyan I. G. \\ Stavropol State Medical University, Russian Federation

\section{ВОЗМОЖНОСТИ АНТИОКСИААНТНОЙ ТЕРАПИИ АККОМОААЦИОННЫХ НАРУШЕНИЙ ПРИ РЕФРАКЦИОННОЙ ПАТОАОГИИ У АЕТЕЙ}

\author{
Н. А. ЧереАниченко, Г. В. Кореняк, Е. С. Нешта, И. Г. Торосян \\ Ставропольский госуАарственный МеАицинский университет, Российская ФеАерация
}

This article presents the results of a study on the effects of including antioxidant therapy in the multimodal treatment of pediatric accommodation disorders in refractive pathology. The results indicate that, among children with myopic refraction, a more pronounced effect occurred in mild and moderate myopia. In children with hyperopic refraction, a more pronounced effect was also found among those with mild and moderate hyperopia. Because accommodative indices increased in all children but did not reach normal values, repeated courses of treatment are recommended two or three times a year.

Keywords: refractive pathology, visual acuity, antioxidant therapy, children

Приведены результаты изучения влияния комплексного лечения аккомодационных нарушений при рефракционной патологии у детей с применением антиоксидантной терапии. Полученные результаты указывают, что в группе детей с миопической рефракцией более выраженный эффект наблюдался при миопии слабой и средней степени. В группе с гиперметропической рефракцией также более выраженный эффект выявлен у детей со слабой и средней степенью гиперметропии. Таким образом, учитывая, что аккомодационные показатели повысились у всех обследованных детей, но не восстановились до нормы, необходимы повторные курсы лечения не менее 2 раз в течение года.

Ключевые слова: рефракционная патология, острота зрения, антиоксидантная терапия, дети

For citation: Cherednichenko N. L., Korenyak G. V., Neshta E. S., Torosyan I. G. THE USE OF ANTIOXIDANT THERAPY IN TREATING PEDIATRIC ACCOMMODATIVE DISORDERS IN REFRACTIVE PATHOLOGY. Medical News of North Caucasus. 2021;16(2):166-168. DOI - https://doi.org/10.14300/mnnc.2021.16037

Для цитирования: Чередниченко Н. Л., Кореняк Г. В., Нешта Е. С., Торосян И. Г. ВОЗМОЖНОСТИ АНТИОКСИДАНТНОЙ ТЕРАПИИ АККОМОДАЦИОННЫХ НАРУШЕНИЙ ПРИ РЕФРАКЦИОННОЙ ПАТОЛОГИИ У ДЕТЕЙ. МЕДИЦИНский вестник Северного Кавказа. 2021;16(2):166-168. DOI - https://doi.org/10.14300/mnnc.2021.16037

APA - anterior-posterior axis of the eye

CRTA - constantly redundant tension of accommodation

Dptr - diopter
RA - accommodation reserves

RAS- relative accommodation stock

The aim of our study was to investigate the effects of antioxidant therapy with the drug Oftalmik in the multimodal treatment of pediatric accommodative disorders in refractive pathology.

Material and Methods. We examined 44 children (88 eyes) with various refractive disorders aged 7-17 years. There were 29 individuals (58 eyes) with myopic refraction, including astigmatism. Of these, 15 had mild myopia ( 30 eyes), 10 had medium myopia (20 eyes), and 4 had high myopia (8 eyes). Fifteen individuals (30 eyes) had hyperopic refraction, including astigmatism. Of these, 4 had mild hyperopia (8 eyes), 5 had medium hyperopia ( 10 eyes), and 6 had high hyperopia (12 eyes).

Children underwent a standard ophthalmological examination: determination of visual acuity with and without correction, measurement of the anteroposterior axis of the eye (APA), and ophthalmoscopy. Refraction was measured in all patients before and after cycloplegia. Reserves and reserves of relative accommodation were investigated before and after treatment. $10-12 \%$ of cases [8-10]. 
The multimodal treatment regimen included dynamic electro-neurostimulation, magnetotherapy, accommodation training according to Dashevsky, and accommodation training according to Avetisov-Mats. The course of hardware treatment comprised 10 procedures. After physical therapy treatment, all children were prescribed Ophthalmic (Vitaukt, Russia), an antioxidant therapy containing taurine, common bilberry, marigold erect, ginkgo biloba, and cultivated grape, which was dosed at two tablets twice daily for one month.

Statistical analysis of the research data was performed using Excel 2010 (Microsoft Corporation, USA) and Statistica 10.0 (StatSoft, Tulsa, OK, USA).

Results and Discussion. Before treatment, patients' functional indices (reserves and reserves of accommodation) measured almost two times below the lower limit (relative to the age norms for emmetropia).

Data analysis revealed that all patients with abnormal refraction who received Oftalmik showed improved visometry indices (average increase of $13 \%$ ). In the group of children with myopic refraction, visual acuity increased by 0.05 (5\%). Visual acuity increased by 0.08 $(8 \%)$ in children with mild myopia, 0.07 (7\%) in children with moderate myopia, and $0.02(2 \%)$ in children with high myopia (Fig. 1).

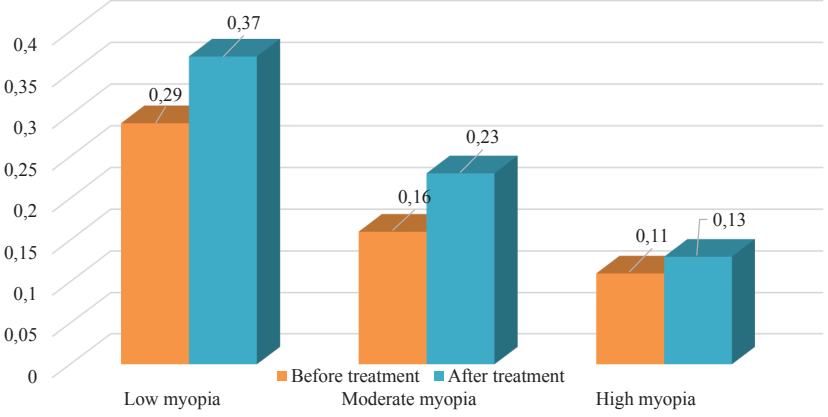

Fig. 1. Dynamics of visual acuity in children with myopic refraction before and after treatment

In the group of children with hyperopic refraction, visual acuity increased by 0.08 (8\%). Visual acuity increased by $0.11(11 \%)$ in children with mild hyperopia and 0.12 (12\%) in children with moderate hyperopia; it remained unchanged in those with high-grade hyperopia (Fig. 2).

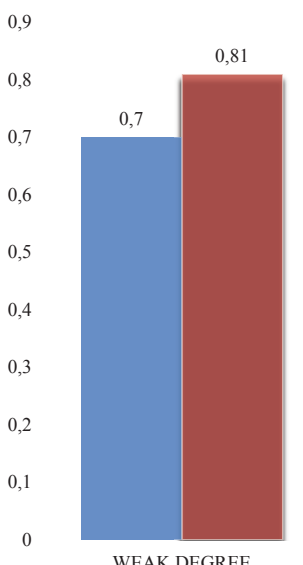

WEAK DEGREE

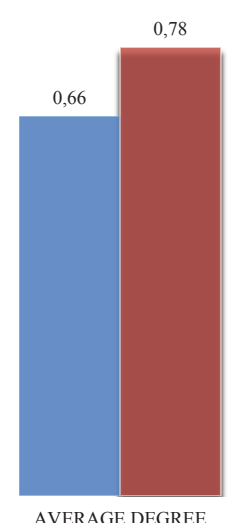

AVERAGE DEGREE before treatment

- after treatment
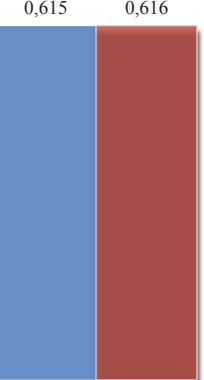

HIGH DEGREE
Fig. 2. Dynamics of visual acuity in children with hyperopic refraction before and after treatment

Improvement in the reserves of relative accommodation (RRA) was observed in all children who received Oftalmik. The positive part of the margin of relative accommo- dation (MRA) in myopia increased by 0.7 diopters, and the negative part increased by 2.25 diopters.

The reserves of accommodation (RA) also improved in all children. Accommodation reserves in myopia increased by 2.89 diopters (Fig. 3).

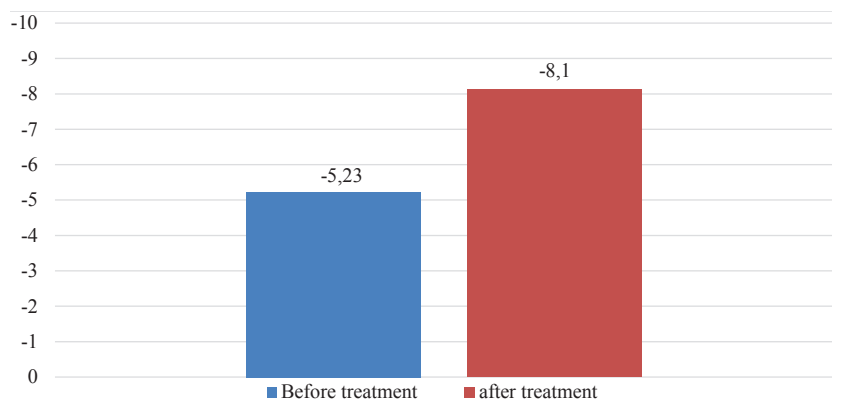

Fig. 3. Dynamics of relative accommodation in children with myopic refraction

In children with hyperopia, the MRA increased by 0.83 diopters in the positive part and 0.78 diopters in the negative part, and the reserves of accommodation increased by 1.75 diopters (Fig. 4).

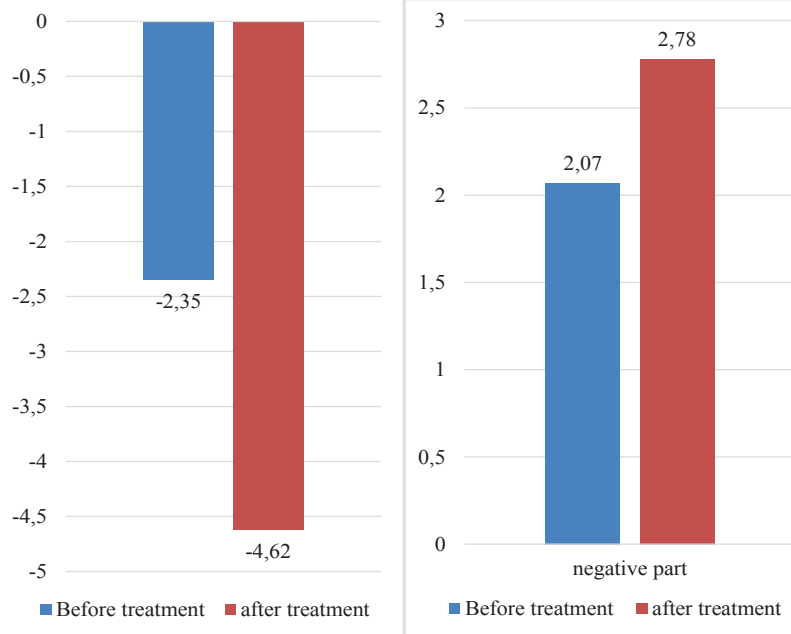

Fig. 4. Dynamics of relative accommodation in children with hyperopic refraction

The pathogenetic mechanisms affecting the development and progression of myopia are still being studied. In addition to external factors, disorders of oxidant/antioxidant balance and ocular hemodynamics play an important role in the formation of myopia, its progression, and the development of accommodation disorders. It is well known that, upon exposure to unfavorable factors, free radical reactions are activated with the formation of secondary radicals that have a damaging effect on cell membranes. The antioxidant defense system, using complex and diverse regulatory mechanisms, prevents the generation of free radicals or inactivates the secondary products of lipid peroxidation (LPO), thereby preventing the development of various pathological conditions [11-13].

In-depth studies performed in recent decades have shown that lipid peroxidation (LPO) of the cell membranes in ocular structures play an essential role in the pathogenesis of many eye diseases, including progressive myopia [14-16]. In these cases, LPO products in the tissues and fluids of the eye increase, and deficits of intraocular antioxidants become more pronounced as the pathology progresses [17]. 
In our study, increases in visual acuity were noted in both refractive groups. Among children with myopic refraction, a more pronounced effect was observed in those with mild and moderate myopia. Among children with hyperopic refraction, a more pronounced effect was also found in children with mild and moderate hyperopia. Although the accommodative indices increased in $100 \%$ of the examined children, they did not reach normal values; accordingly, we recommend repeated courses of treatment two or three times a year.

Conclusions. This study shows that including the antioxidant drug Ophthalmic in the multimodal treatment of children with refractive pathology has a positive effect on visual acuity and the state of accommodation. This therapy is most effective in children with mild to moderate myopia and hyperopia.

Disclosures: The authors declare no conflicts of interest.

Acknowledgment. We thank Edanz (www.edanz.com/ac) for editing a draft of this manuscript.

\section{References}

1. Wojciechowski R. Nature and nurture: the complex genetics of myopia and refractive error. Clin. Genet. 2011;79(4):301320. https://doi.org/10.1111/j.1399-0004.2010.01592.x

2. Morgan I. G., French A. N., Ashby R. S., Guo X., Ding X. [et al.] The epidemics of myopia: Aetiology and prevention. Prog. Retin. Eye Res. 2018;62(1):134-149. https://doi.org/10.1016/j.preteyeres.2017.09.004

3. Williams K. M., Bertelsen G., Cumberland P., Wolfram C., Verhoeven V. J., Anastasopoulos E. Increasing prevalence of myopia in Europe and the impact of education. Ophthalmology. 2015;122(7):1489-1497. https://doi.org/10.1016/j.ophtha.2015.03.018

4. Katargina L. A., Mihajlova L. A. The state of the children's ophthalmological service of the Russian Federation. Russian Pediatric Ophthalmology. 2015;1:5-10.

5. Holden B. A., Fricke T. R., Wilson D. A., Jong M., Naidoo K. S. [et al.] Global prevalence of myopia and high myopia and temporal trends from 2000 through 2050. Ophthalmology. 2016;123:1036-1042.

https://doi.org/10.1016/j.ophtha.2016.01.006

6. Neroyev V. V. Eye care management in Russian Federation. Vestnik Oftalmologii. 2014;130(6):8-12.

7. Tarutta E. P., Proskurina O. V., Tarasova N. A., Markosyan G. A. Analysis of risk factors that cause myopia in pre-school children and primary school students. Health Risk Analysis. 2019;3:26-33 https://doi.org/10.21668/health.risk/2019.3.03.eng

8. Markova E. Y., Pron'ko N. A., Aminulla L. V., Venediktova L. V., Bezmelnitsyna L. Y. To the Question of School Myopia. Ophthalmology in Russia. 2018;15(1):87-91. https://doi.org/10.18008/1816-5095-2018-1-87-91

9. Chamberlain P., Peixoto-de-Matos, Logan N. S., Ngo C., Jones D. [et al.] A 3-year randomized clinical trial of MiSight lenses for myopia control. Optom. Vis. Sci. 2019;98(8):556567.

10. Proskurina O. P., Markova E. Yu., Brzheskij V. V., Efimova $\mathrm{E}$. L., Efimova M. N. [et al.] The prevalence of myopia in schoolchildren in some regions of Russia. Ophthalmology in Russia. 2018;15(3):348-353.

https://doi.org/10.18008/1816-5095-2018-3-348-353

11. Sysolyatin S. V., Kryukov Y. A., Anfinogenova Y., Plotnikova T. M., Plotnikov M. B. Neuroprotective effects of p-tyrosol after the global cerebral ischemia in rats. Phytomedicine. 2016;23(7):784-792

https://doi.org/10.1016/j.phymed.2016.03.015

12. Terekhov R. P., Selivanova I. A. Molecular modeling of the interaction of the dihydroquercetin and its metabolites with cyclooxygenase-2. Bulletin of Siberian Medicine. 2019;18(3):101-106 https://doi.org/10.20538/1682-0363-2019-3-101-106

13. Tarutta E. P., lomdina E. N., Tarasova N. A., Markosyan G. A., Maksimova M. V. Complex approach to the prevention and treatment of progressive myopia in school children. RMJ «Clinical ophthalmology». 2018;2:70-76. https://doi.org/10.21689/2311-7729-2018-18-2-70-76

14. Zhou S., Yang L., Lu B., Wang H., Xu T. [et al.] Association between parents' attitudes and behaviors toward children's visual care and myopia risk in school-aged children (metaanalis). Medicine. 2017;96(52):e9270. https://doi.org/10.1097/MD.0000000000009270

15. Holden B. A Timothy R. F., Wilson D. A Jong M. Naidoo K. S. [et al.] Global Prevalence of Myopia and High Myopia and Temporal Trends from 2000 through 2050. Ophthalmology. 2016;123(5):1036-1042.

16. Lankin V. Z Tikhaze A. K. Results of the study of the pathophysiological effects of dysregulation of free-radical processes: deadlock or a new impulse? Acta Biomedica Scientifica. 2016;1(3(2)):160-167.

h t t p s: / / d o i. o r g / 10 . $12737 /$ article_590823a5489433.14864804

17. Proskurina O. V., Tarasova N. A., Tarutta E. P., Proskurina O. V., Tarasova N. A. [et al.] Accommodation disorders often precede the development and progression of myopia in children. Modern optometry. 2018;18(8):25-29.

\section{About authors:}

Cherednichenko Nina Lvovna, CMSc, Associate Professor, Head of Department of ophthalmology; tel.: +79624459471; e-mail: r6hn@bk.ru; https://orcid.org/0000-0002-3624-588

Korenyak Galina Viktorovna, CMSc, Associate Professor in Department of ophthalmology; e-mail: gkorenyak@bk.ru; https://orcid.org/0000-0001-9768-8419

Neshta Evgenia Sergeevna, CMSc, Assistant of the Department of public health and health care; e-mail: neshta2022@mail.ru; https://orcid.org/0000-0001-9911-4857

Torosyan Igor Georgievich, Senior lecturer of Department of physical culture and adaptive physical education; e-mail: ra6fw@bk.ru; https://orcid.org/0000-0002-1140-4604 